Jurnal Mandala Pharmacon Indonesia, Vol 5.No.2 Desember 2019

Avaiable online at www.jurnal-pharmaconmw.com/jmpi

p-ISSN : 2442-6032

$e$-ISSN : 2598-9979

\title{
Uji Ekstrak Etanol Daun Kemangi Terhadap Kadar Glukosa Darah, Dan Gambaran Histopatologi Pankreas Tikus Yang Diinduksi Streptozotocin
}

\author{
Joni Tandi, Niswatulfahriyati, Nurmadinah, Tien Wahyu Handayani \\ Program Studi S1 Farmasi, Sekolah Tinggi Ilmu Farmasi Pelita Mas
}

\begin{abstract}
ABSTRAK
Penelitian ini bertujuan menguji ada tidaknya kandungan senyawa metabolit sekunder pada ekstrak etanol daun kemangi,efek penurunan kadar glukosa darah dari ekstrak etanol daun kemangipada tikus putih jantan yang diinduksi streptozotocin.Penelitian ini merupakan penelitian eksperimen laboratorium dengan menggunakan hewan uji sebanyak 30 ekor tikus putih jantan dibagi menjadi 6 kelompok dan tiap kelompok terdiri dari 5 ekor tikus dengan rincian kelompok I sebagai kontrol normal, kelompok II sebagai kontrol negatif yang diberikan suspensi Na-CMC 0,5\%, kelompok III sebagai kontrol positif yang diberikan suspensi glibennklamide

tingkat kerusakan pankreas menggunakan uji Kruskal-Wallis, sedangkan untuk melihat perbedaan antar perlakuan dilanjutkan dengan uji Mann-Whitney. Hasil penelitian menunjukkan bahwa terdapat senyawa metabolit sekunder pada ekstrak etanol daun kemangi yaitu flavonoid, saponin, dan tanin: pemberian ekstrak etanol daun kemangi memberikan efek menurunkan kadar glukosa darah pada tikus putih yang diinduksi streptozotocin: Hasil penelitian menunjukkan bahwa pengaruh ekstrak etanol daun kemangi yang memberikan hasil yang maksimal untuk menurunkan kadar glukosa darah dan regenerasi jaringan pankreas
\end{abstract} dan kelompok IV,V,VI sebagai kelompok uji diberikan ekstrak etanol daun keamngi, dengan masing-masing dosis $200 \mathrm{mg} / \mathrm{kg} \mathrm{BB}, 400 \mathrm{mg} / \mathrm{kg}$ BB dan 80omg/kg BB . Perlakuan diberikan selama 14 hari dan pada hari ke-o, 7,14, 21 dan 28 dilakukan pengukuran kadar glukosa dengan menggunakan glukometer. Data hasil pengujian kadar glukosa darah menggunakan uji one way Anova pada tariff kepercayaan 95\% kemudian dilanjutkan dengan uji Least Significant Difference (LSD), dan analisis hasil skoring

Kata kunci : Ekstrak etanol, daun kemangi (Ocimum basilicum L.), diabetes, histopatologi pancreas.

\section{Penulis korespondensi :}

Joni Tandi

Program Studi S1 Farmasi, Sekolah Tinggi Ilmu

Farmasi Pelita Mas

E-mail : jonitandi757@yahoo.com

\section{PENDAHULUAN}

Diabetes melitus (DM) adalah penyakit metabolik yang ditandai dengan tingginya kadar glukosa darah (hyperglikemia) sebagai akibat dari kekurangan sekresi insulin, gangguan aktivitas insulin atau keduanya (American Diabetes Association (ADA),2004). Hiperglikemia adalah suatu kondisi medik berupa peningkatan kadar glukosa dalam darah melebihi batas normal (PERKENI,2015). Diabetes melitus terjadi bila insulin yang dihasilkan tidak cukup untuk mempertahankan gula darah dalam batas normal atau jika sel tubuh tidak mampu berespon dengan tepat sehingga akan muncul keluhan khas diabetes melitus berupa poliuria, polidipsi, polifagia, penurunan berat badan, kelemahan, kesemutan, pandangan kabur dan disfungsi ereksi pada laki-laki dan pruritus vulvae pada wanita. (Santi $\mathrm{D}$,2015).

Kondisi kronis yang terjadi ketika kadar glukosa darah berada diatas norma akibat pankreas tidak cukup untuk 
memproduksi insulin atau tidak efektifnya tubuh dalam menggunakan insulin yang diproduksi (Tandi J. 2016). Salah satu masalah kesehatan masyarakat yang sangat serius dan membutuhkan penanganan yang tepat bagi penderitanya adalah DM. Meningkatnya kadar glukosa dalam plasma darah melebihi batas normal menjadi salah satu dasar diagnosis DM (Aer N. Brenda. 2013). DM disebabkan oleh rusaknya sel $\beta$ dari pulau langerhans pankreas yang berfungsi menghasilkan insulin akibat keadaan hiperglikemia. Menurut Rizzal (2010), satu jam setelah konsumsi karbohidrat tinggi menyebabkan terjadinya peningkatan kadar gula darah secara cepat.

Keadaan peningkatan kadar glukosa darah secara tiba-tiba dapat memicu stres oksidatif yaitu pada fase transport elektron, menyebabkan anion superoksida akan dirubah menjadi hidrogen peroksida sehingga terjadi apoptosis (Laxmi N. Suci. 2017). Pengontrolan kadar glukosa darah mendekati normal dengan cara pemberian obat hipoglikemik oral atau antihipoglikemik oral dan insulin merupakan salah satu tujuan utama terapi medis bagi pasien DM. Namun pemberian obat hipoglikemik oral dapat memberikan efek samping yang tidak di inginkan, selain itu harga obat hipoglikemik oral juga kurang terjangkau oleh masyarakat luas. Sehingga menyebabkan meningkatnya ketertarikan masyarakat untuk menggunakan sumber alam seperti tumbuhan sebagai alternatif menangani DM. (Aer N. Brenda. 2013).

Salah satu tanaman tradisional yang berkhasiat sebagai obat adalah kemangi (Ocimum basilicum L.). Kemangi merupakan tanaman yang umum bagi masyarakat, kemangi yang biasa dikonsumsi masyarakat sebagai bahan pelengkap lalapan di berbagai warung makan. Selain itu, karena baunya yang harum (Savira. 2012). Serat kasar kemangi dilaporkan dapat menurunkan kadar kolesterol dan kadar gula darah serta menurunkan resiko hipertensi dan penyakit kardiovaskuler (Ikhlas N. 2013). Kemangi (Ocimum basilicum L) memiliki senyawa aktif yaitu tanin, flavonoid, saponin dan alkaloid (Wibowo A. Arianto, 2012).

Penelitian sebelumnya efek antidiabetes dengan menggunakan daun kemangi (Ocimum basilicum L)telah dilakukan antara lain yaitu penelitian yang menggunakan ekstrak etanol daun kemangi pada dosis $800 \mathrm{mg} / \mathrm{kg}$ BB dapat menurunkan kadar glukosa darah yaitu sebesar 61,80\% (Manasika A, 2014).Penelitian lain menyatakan bahwa daun kemangi pada dosis $400 \mathrm{mg} / \mathrm{kg} \mathrm{BB}$, $800 \mathrm{mg} / \mathrm{kg} \mathrm{BB}$ memberikan pengaruh yang sangat signifikan terhadap penurunan kadar glukosa darah yaitu $57,25 \mathrm{mg} / \mathrm{dl}$ dan $80,05 \mathrm{mg} / \mathrm{dl}$ pada tikus putih jantan yang diinduksi aloksan(priyambodo D, 2010).Penelitian lainnya lagi menyatakan bahwa daun kemangi pada dosis $400 \mathrm{mg} / \mathrm{kg} \mathrm{BB}$ dapat menurunkan kadar glukosa darah yaitu sebesar 101,45 mg/dl (117,63\%)(Ezeani et al,2016).

Berdasarkan uraian di atas maka peneliti tertarik untuk melakukan penelitian lebih lanjut, untuk mengetahui efek ekstrak etanol daun kemangi dalam memberikan hasil yang maksimal untuk menurunkan kadar glukosa darah dan regenerasi jaringan pankreas tikus putih jantan yang diinduksi streptozotocin. Penelitian ini diharapkan dapat menjadi sumber informasi baru untuk masyarakat tentang daun kemangi. 
METODE PENELITIAN

Alat dan Bahan

Alat

Batang pengaduk, blender, corong pisah, tabung reaksi, gelas kimia $50 \mathrm{ml}$, gelas kimia $100 \mathrm{ml}$, gelas kimia $250 \mathrm{ml}$, gelas ukur $10 \mathrm{ml}$, gelas ukur $100 \mathrm{ml}$, gelas ukur $250 \mathrm{ml}$, glukometer (ACCU CHEK), glukotest trip test,100 dan $250 \mathrm{ml}$, lumpang dan alu, penangas air,rotavapor, spoit injeksi 1, 3 dan $5 \mathrm{ml}$, sterofom, pinset, tabung organ, pisau bedah, gunting bedah, timbangan analitik dan timbangan hewan uji.

\section{Bahan}

Daun kemangi (Ocimum basilicum L) yang diambil dari desa Bobalo, kecamatan palasa, kabupaten parigi moutong, provinsi sulawesi tengah. Tikus putih jantan galur wistar, etanol 96\% Aqua destilata, aqua pro injeksi,asam klorida, besi(III) klorida, Citrate-buffer saline (Natrium sitrat, asam sitrat), dragendrof

LP,eter,formalin 10\%,glibenklamid, handskun, kapas, kertas label, kertas saring, lakban, Libermann-burchard, masker, Na CMC 0,5\%, natrium klorida, pakan standar, larutan mayers Hematoxylin Eosin, serbuk magnesium, streptozotocin,tissue dan Xylol.

\section{Pembuatan Ekstrak Etanol Daun} Kemangi,

Pembuatan ekstrak daun kemangi

(Ocimum basilicum L) Pembuatan ekstrak dilakukan secara maserasi menggunakan pelarut etanol 96\%, cara kerjanya yaitu serbuk daun kemangi dimasukan kedalam wadah botol berwarna gelap, kemudian ditambahkan pelarut etanol 96\%,selanjutnya ditutup dan dibiarkan selama 3 hari terlindung dari cahaya sambil diaduk,disaring sehingga di dapat maserat. Dilakukan sampai diperoleh maserat yang
jernih.Semua maserat digabungkan kemudian diuapkan dengan menggunakan alat Rotary Vaccum Evaporator pada suhu $60^{\circ} \mathrm{C}$ hingga diperoleh ektrak kental.

\section{Pembuatan Larutan Koloidal Na CMC o,5\%}

Natrium karboksimetil selulosa ( $\mathrm{Na}$ CMC) ditimbang sebanyak 0,5 gram kemudian dimasukkan kedalam lumpang yang terlah berisi $10 \mathrm{ml}$ aquades yang telah di panaskan. Didiamkan selama 15 menit hingga terbentuk massa yang transparan, lalu campurkan hingga homogen. Kemudian larutan Na CMC dipindahkan ke dalam labu ukur $100 \mathrm{ml}$. Volumenya dicukupkan dengan aquades hingga $100 \mathrm{ml}$.

\section{Pembuatan \\ Glibenklamide}

Suspensi

Dosis glibenklamid pada manusia dewasa adalah $5 \mathrm{mg}$ per hari, jika dikonversi pada tikus dengan berat 200 gram adalah 0,018 maka dosis glibenklamid untuk tikus adalah o,45 $\mathrm{mg} / \mathrm{kg}$ BB. Ditimbang serbuk tablet glibenklamid yang setara dengan 3,6 mg kemudian disuspensi dalam $\mathrm{Na} \mathrm{CMC}$ 0,5\% hingga $100 \mathrm{ml}$ kemudian dikocok hingga homogen.

\section{Pembuatan Larutan Streptozotocin (STZ)}

Sebanyak 0,32 gram streptozotocin ditimbang lalu dilarutkan dalam citratebuffer saline denganpH 4,5 sampai 100 ml, kemudian diinduksikan pada tikus melalui intraperitoneal (ip). Dosis streptozotocin yang digunakan yaitu 40 $\mathrm{mg} / \mathrm{kg} \mathrm{BB}$.

\section{Analisis Data}

Data yang diperoleh berupa kadar glukosa darah yang dianalisis secara statistik menggunakan analisis anovasatu arah (One Way Anova) pada taraf kepercayaan 95\%, selanjutnya dilakukan 
uji post hoc Least Significant Difference (LSD) untuk mengetahui perbedaan yang bermakna antara perlakuan. Pengolahan data dilakukan dengan menggunakan program software SPSS 23. Uji Kruskal-
Wallis digunakan untuk menganalisis data skoring kerusakan pulau langerhans yang dilanjutkan dengan uji MannWhitney untuk mengetahui perbedaan antar semua kelompok perlakuan.

\section{HASIL DAN PEMBAHASAN}

Tabel 1. Hasil Uji Fitokimia Ekstrak Etanol Daun Kemangi

\begin{tabular}{lcl}
\hline No & Pengujian & Hasil \\
\hline 1 & Uji Alkaloid & Negatif(-) \\
\hline 2 & Uji Flavonoid & Positif $(+)$ \\
\hline 3 & Uji saponin & Positif $(+)$ \\
\hline 4 & Uji Tanin & Positif $(+)$ \\
\hline
\end{tabular}

Keterangan :

(+) : Mengandung golongan senyawa yang diuji.

Tabel 2. Rerata Hasil Pengukuran Kadar Glukosa Darah

Rerata \pm SD Kadar Glukosa Darah (mg/dL)

\begin{tabular}{|c|c|c|c|c|c|c|c|}
\hline $\begin{array}{c}\text { Hari } \\
\text { ke }\end{array}$ & $\begin{array}{l}\text { Kontrol } \\
\text { Normal }\end{array}$ & $\begin{array}{l}\text { Kontrol } \\
\text { Negatif }\end{array}$ & $\begin{array}{l}\text { Kontrol positif } \\
\text { (Glibenklamid) }\end{array}$ & $\begin{array}{l}\text { Dosis } 200 \\
\mathrm{mg} / \mathrm{kgBB}\end{array}$ & $\begin{array}{l}\text { Dosis } 200 \\
\mathrm{mg} / \mathrm{kgBB}\end{array}$ & $\begin{array}{l}\text { Dosis } 200 \\
\mathrm{mg} / \mathrm{kgBB}\end{array}$ & $\mathrm{P}$ \\
\hline $\mathrm{O}$ & $\begin{array}{l}78,6+61 \\
07\end{array}$ & $\begin{array}{l}75,2+13, \\
863\end{array}$ & $70,4+7,635$ & $\begin{array}{l}88,2+8,7 \\
86\end{array}$ & $\begin{array}{l}95,2+12,6 \\
76\end{array}$ & $94+11,113$ & $\begin{array}{l}0,00 \\
3\end{array}$ \\
\hline 7 & $\begin{array}{l}81,6+8,1 \\
11\end{array}$ & $\begin{array}{l}404+16, \\
658\end{array}$ & $366,4+21,893$ & $\begin{array}{l}379,8+60, \\
743\end{array}$ & $\begin{array}{l}413,4+46, \\
436\end{array}$ & $\begin{array}{l}380,8+71, \\
188 \\
\end{array}$ & $\begin{array}{l}0,56 \\
5 \\
\end{array}$ \\
\hline 14 & $\begin{array}{l}83,2+79 \\
49\end{array}$ & $\begin{array}{l}369,8+4 \\
9,414\end{array}$ & $232,4+11,61$ & $\begin{array}{l}249,4+56, \\
849\end{array}$ & $\begin{array}{l}245,4+32, \\
86\end{array}$ & $\begin{array}{l}324,8+16, \\
843\end{array}$ & $\begin{array}{l}0,00 \\
0\end{array}$ \\
\hline 21 & $\begin{array}{l}86,6+8,2 \\
64\end{array}$ & $\begin{array}{l}232+31 \\
544\end{array}$ & $97,2+4,604$ & $\begin{array}{l}162+82,8 \\
13\end{array}$ & $\begin{array}{l}155,4+39, \\
595\end{array}$ & $\begin{array}{l}149,4+13 \\
795\end{array}$ & $\begin{array}{l}0,00 \\
2\end{array}$ \\
\hline 28 & $\begin{array}{l}89,4+9,3 \\
16\end{array}$ & $\begin{array}{l}228,6+3 \\
1214\end{array}$ & $77,8+6,418$ & $\begin{array}{l}150+67,77 \\
9\end{array}$ & $\begin{array}{l}119,6+3,8 \\
47\end{array}$ & $\begin{array}{l}114,6+6,6 \\
93\end{array}$ & $\begin{array}{l}0,00 \\
0\end{array}$ \\
\hline
\end{tabular}

Sumber : Data Primer 2018

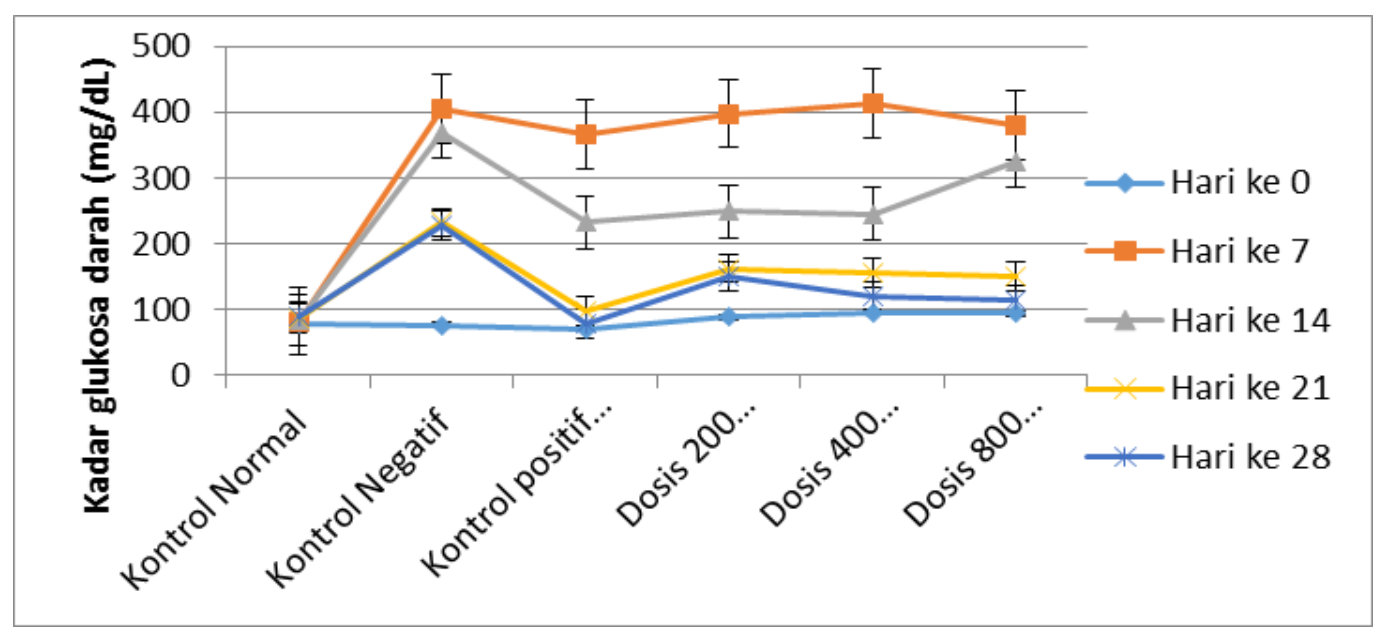

Gambar 1. Grafik hasil pengukuran kadar glukosa darah tikus putih jantan setiap kelompok pada hari ke o, ke 7 , ke 14, ke 21 dan ke 28 
Tabel 3. Hasil Skoring Histologi Pankreas Tikus

\begin{tabular}{|c|c|c|c|c|c|c|c|}
\hline \multirow{2}{*}{$\begin{array}{l}\text { Kelompok } \\
\text { perlakuan }\end{array}$} & \multirow[t]{2}{*}{ Tikus } & \multicolumn{5}{|c|}{ Skoring kerusakan } & \multirow{2}{*}{$\begin{array}{l}\text { Rata-rata } \pm \text { SD } \\
\text { Kerusakan }\end{array}$} \\
\hline & & 0 & 1 & 2 & 3 & 4 & \\
\hline \multirow[t]{5}{*}{ Kontrol normal } & 1 & $\mathrm{O}$ & - & - & - & - & \multirow{5}{*}{$\mathrm{O} \pm \mathrm{O}$} \\
\hline & 2 & $\mathrm{O}$ & - & - & - & - & \\
\hline & 3 & $\mathrm{O}$ & - & - & - & - & \\
\hline & 4 & 0 & - & - & - & - & \\
\hline & 5 & O & - & - & - & - & \\
\hline \multirow{5}{*}{$\begin{array}{l}\text { Kontrol Negatif } \\
\text { (Streptozotocin) }\end{array}$} & 1 & - & - & - & 3 & - & \multirow{5}{*}{$3,2 \pm 0,447$} \\
\hline & 2 & - & - & - & 3 & - & \\
\hline & 3 & - & - & - & 3 & - & \\
\hline & 4 & - & - & - & 3 & - & \\
\hline & 5 & - & - & - & - & 4 & \\
\hline \multirow{5}{*}{$\begin{array}{l}\text { Kontrol positif } \\
\text { (Glibenklamid) }\end{array}$} & 1 & $\mathrm{O}$ & - & & - & - & \multirow{5}{*}{$0,8 \pm 0,836$} \\
\hline & 2 & - & - & 2 & - & - & \\
\hline & 3 & - & 1 & - & - & - & \\
\hline & 4 & & 1 & - & - & - & \\
\hline & 5 & $\mathrm{O}$ & - & - & - & - & \\
\hline \multirow{5}{*}{$\begin{array}{c}\text { Ekstrak Etanol } \\
\text { daun kemangi } \\
\text { dosis } 200 \mathrm{mg} \\
\mathrm{mg} / \mathrm{kgBB}\end{array}$} & 1 & - & - & 2 & - & - & \multirow{5}{*}{$1,4 \pm 0,547$} \\
\hline & 2 & - & - & 2 & - & - & \\
\hline & 3 & - & 1 & - & - & - & \\
\hline & 4 & - & 1 & - & - & - & \\
\hline & 5 & - & 1 & - & - & - & \\
\hline \multirow{5}{*}{$\begin{array}{c}\text { Ekstrak Etanol } \\
\text { daun kemangi } \\
\text { dosis } 400 \mathrm{mg} \\
\text { mg/kgBB }\end{array}$} & 1 & - & - & 2 & - & - & \multirow{5}{*}{$0,8 \pm 0,836$} \\
\hline & 2 & $\mathrm{O}$ & - & - & - & - & \\
\hline & 3 & 0 & - & - & - & - & \\
\hline & 4 & - & 1 & - & - & - & \\
\hline & 5 & - & 1 & - & - & - & \\
\hline \multirow{5}{*}{$\begin{array}{c}\text { Ekstrak Etanol } \\
\text { daun kemangi } \\
\text { dosis } 800 \mathrm{mg} \\
\mathrm{mg} / \mathrm{kgBB}\end{array}$} & 1 & $\mathrm{O}$ & - & - & - & - & \multirow{5}{*}{$0,2 \pm 0,447$} \\
\hline & 2 & 0 & - & - & - & - & \\
\hline & 3 & $\mathrm{O}$ & - & - & - & - & \\
\hline & 4 & - & 1 & - & - & - & \\
\hline & 5 & 0 & - & - & - & - & \\
\hline
\end{tabular}

\section{Keterangan}

Skor $\mathrm{O}=$ tidak ada kerusakan

Skor $1=$ kerusakan $1 / 4$ bagian sel

Skor $2=$ kerusakan $1 / 2$ bagian sel

Skor $3=$ kerusakan $3 / 4$ bagian sel

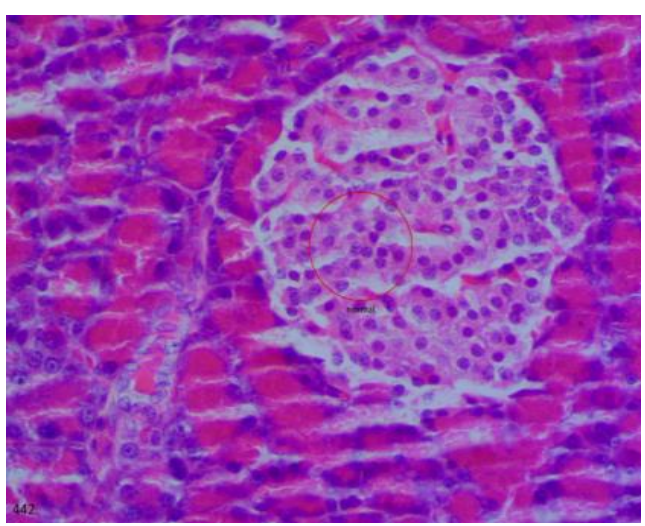

(A)

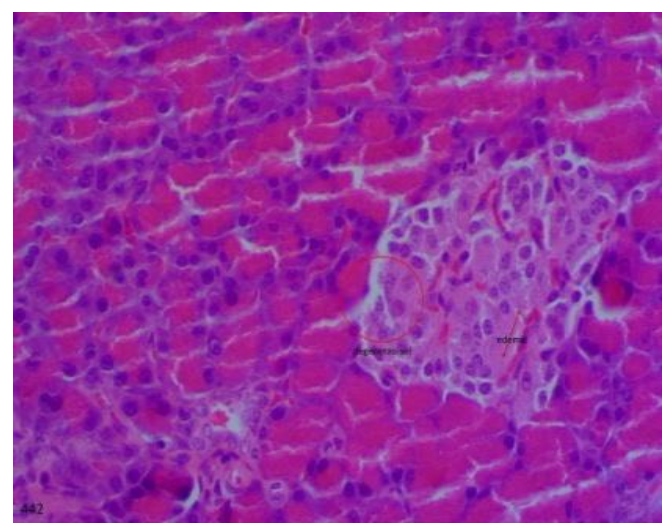

(B) 


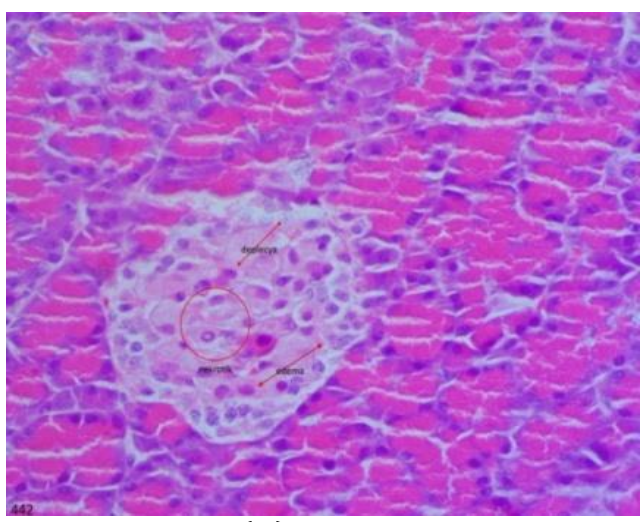

(C)

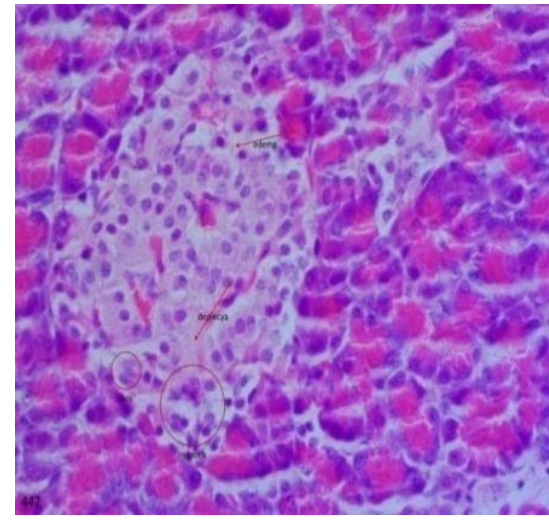

(D)

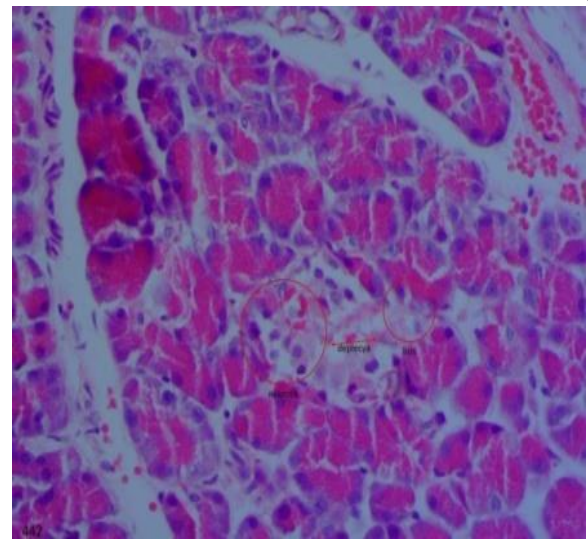

(E)

Keterangan :

Gambar 2. Gambaran histologi jaringan pankreas tikus

A = Preparat Jaringan Pankreas Tikus Putih Skor o (Normal) Pewarnaan HE Perbesaran 400X

B $=$ Preparat Jaringan Pankreas Tikus Putih Skor 1 Pewarnaan HE Perbesaran 40oX (kerusakan 1/4 bagian sel. sel mengalami piknosis)

$\mathrm{C}=$ Preparat Jaringan Pankreas Tikus Putih Skor 2 Pewarnaan HE Perbesaran 400X Keterangan (kerusakan $1 / 2$ bagian sel, sel mengalami degenerasi, piknosis dan atropi)

D = Preparat Jaringan Pankreas Tikus Putih Skor 3 Pewarnaan HE Perbesaran 40oX (kerusakan 3/4 bagian sel, sel mengalami karyolisis, piknosis)

E $=$ Preparat Jaringan Pankreas Tikus Putih Skor 4 Pewarnaan HE Perbesaran 40oX (kerusakan hampir seluruh bagian sel, sel mengalami karyolisis, piknosis)

Tabel 4. Hasil Statistik Man-Whitney

\begin{tabular}{|c|c|c|c|c|c|c|}
\hline $\mathrm{P}$ & $\begin{array}{c}\text { Kontrol } \\
\text { normal }\end{array}$ & $\begin{array}{l}\text { Kontrol } \\
\text { Negatif }\end{array}$ & $\begin{array}{c}\text { Kontrol } \\
\text { positif }\end{array}$ & $\begin{array}{c}\text { dosis } 200 \\
\text { mg } \\
\mathrm{mg} / \mathrm{kgBB}\end{array}$ & $\begin{array}{c}\text { dosis } 400 \\
\text { mg } \\
\mathrm{mg} / \mathrm{kgBB}\end{array}$ & $\begin{array}{c}\text { dosis } 800 \\
\mathrm{mg} \\
\mathrm{mg} / \mathrm{kgBB}\end{array}$ \\
\hline $\begin{array}{l}\text { Kontrol } \\
\text { normal }\end{array}$ & - & $0,004^{*}$ & 0,053 & $0,005^{*}$ & 0,053 & 0,317 \\
\hline $\begin{array}{c}\text { Kontrol } \\
\text { Positif }\end{array}$ & 0,053 & $0,007^{*}$ & - & 0,212 & 1,000 & 0,189 \\
\hline $\begin{array}{c}\text { Kontrol } \\
\text { negatif }\end{array}$ & $0,004^{*}$ & - & $0,007^{*}$ & $0,006^{*}$ & 0,053 & $0,005^{*}$ \\
\hline $\begin{array}{l}\text { Dosis } 200 \\
\mathrm{mg} / \mathrm{kgBB}\end{array}$ & $0,005^{*}$ & $0,006^{*}$ & 0,212 & - & 0,212 & $0,014^{*}$ \\
\hline $\begin{array}{l}\text { Dosis } 400 \\
\mathrm{mg} / \mathrm{kgBB}\end{array}$ & 0,053 & 0,053 & 1,000 & 0,212 & - & 0,189 \\
\hline $\begin{array}{l}\text { Dosis } 800 \\
\mathrm{mg} / \mathrm{kgBB}\end{array}$ & 0,317 & $0,005^{*}$ & 0,189 & $0,014^{*}$ & 0,189 & - \\
\hline
\end{tabular}

Keterangan : * Berbeda Signifikan 


\section{PEMBAHASAN}

Penelitian ini menggunakan tikus putih jantan (Rattus norvegicus) sebagai hewan uji. Hasil pengukuran kadar glukosa darah pada hari ke-o dapat lihat pada (tabel 4.2) dimana hasil pengukuran kadar glukosa awal adalah $76 \mathrm{mg} / \mathrm{dL}-$ $103 \mathrm{mg} / \mathrm{dL}$, kadar glukosa darah tersebut dinyatakan normal, mg/dL (Dwinthasari M.A. 2015).

Hasil pengukuran kadar karena berada dalam range 50 - 135 glukosa darah tikus putih jantan (Rattus norvegicus) pada hari ke-7 setelah diinduksi streptozotocim dosis $40 \mathrm{mg} / \mathrm{kg}$ BB yaitu berada pada kadar $375 \mathrm{mg} / \mathrm{dL}$ $469 \mathrm{mg} / \mathrm{dL}$ dapat lihat pada (tabel 4.2). Apabila kadar glukosa darah melebihi $200 \mathrm{mg} / \mathrm{dL}$, maka tikus dinyatakan hiperglikemia (Sari, D.P. 2016). Kenaikan kadar glukosa darah disebabkan pemberian streptozotocin dosis $40 \mathrm{mg} / \mathrm{kg}$ BB secara i.p. Mekanisme kerja streptozotocin menyebabkan hiperglikemia dengan cara streptozotocin masuk ke sel $\beta$ pankeas melalui glucose transporter (GLUT 2) dan menginhibisi siklus krebs menginduksi NO sehingga menyebabkan kerusakan DNA. Gugus alkil yang terdapat pada streptozotocin menyebabkan alkalisasi DNA. Alkalisasi tersebut akan mengaktifan poli (ADP ribosilasion) yang membuat penurunan NAD dan ATP yang memyebabkan kerusakan pada sel $\beta$ pankreas (Suryani, N. et al. 2013).

Berdasarkan hasil statistik one way Anova pada hari ke-14 menunjukkan nilai $\mathrm{P}=0$,000 $\quad(\mathrm{P}<0,05)$ yang menunjukkan semua kelompok perlakuan berbeda signifikan yang artinya streptozotocin memberikan efek, sehingga dilanjutkan uji untuk melihat perbedaan yang bermakna antar kelompok dengan menggunakan uji lanjut post hoc LSD.
Hasil uji lanjut post hoc LSD menunjukkan bahwa kontrol negatif berbeda signifikan dengan semua kelompok perlakuan.Kontrol positif tidak berbeda signifikan dengan kelompok dosis $200 \mathrm{mg} / \mathrm{kg}$ BB dan $400 \mathrm{mg} / \mathrm{kg} \mathrm{BB}$, tetapi berbeda signifikan dengan kontrol sakit dan kelompok dosis $800 \mathrm{mg} / \mathrm{kg}$ BB. Hal ini disebabkan karena pada kontrol sakit dan kelompok dosis $800 \mathrm{mg} / \mathrm{kg} \mathrm{BB}$, kadar glukosa darah hewan uji masih cukup tinggi dibandingkan dengan kadar glukosa darah hewan uji kontrol positif, kelompok dosis $200 \mathrm{mg} / \mathrm{kg}$ BB dan 400 $\mathrm{mg} / \mathrm{kg}$ BB sedangkan kontrol positif tidak berbeda signifikan dengan kelompok dosis $200 \mathrm{mg} / \mathrm{kg} \mathrm{BB}, 400 \mathrm{mg} / \mathrm{kg} \mathrm{BB}$ dan $800 \mathrm{mg} / \mathrm{kg}$ BB. Hal ini menunjukkan bahwa semua kelompok dosis sudah dapat memberikan efek sebanding dengan kontrol positif tetapi berbeda signifikan dengan kontrol sakit yang tidak diberikan perlakuan.

Hasil statistik one way Anova pada hari ke-21 meperlihatkan nilai $\mathrm{P}=0,002$ $(\mathrm{P}<0,05)$ yang menunjukkan terdapat perbedaan signifikan pada semua kelompok perlakuan, yang artinya ada efek glibenklamid maupun ekstrak dosis $200 \mathrm{mg} / \mathrm{kg} \mathrm{BB}, 400 \mathrm{mg} / \mathrm{kg}$ BB dan 800 $\mathrm{mg} / \mathrm{kg} \mathrm{BB}$, sehingga dilanjutkan dengan uji post hoc LSD untuk melihat perbedaan yang bermakna antar kelompok perlakuan. Hasil uji post hoc LSD menunjukkan bahwa kontrol sakit berbeda signifikan dengan semua kelompok perlakuan, sedangkan kontrol positif berbeda signifikan dengan kontrol sakit, tetapi tidak berbeda signifikan dengan kelompok dosis $200 \mathrm{mg} / \mathrm{kg} \mathrm{BB}$, $400 \mathrm{mg} / \mathrm{kg}$ BB dan $800 \mathrm{mg} / \mathrm{kg}$ BB. Hal ini menunjukkan bahwa ada efek yang dihasilkan ekstrak etanol daun kemangi karena penurunan kadar glukosa darah 
kelompok dosis sudah sebanding dengan kontrol positif.

Hasil statistik one way Anova pada hari ke-28 meperlihatkan nilai $\mathrm{P}=0,000$ $(\mathrm{P}<0,05)$ yang menunjukkan terdapat perbedaan signifikan pada semua kelompok perlakuan, yang artinya ada efek glibenklamid maupun ekstrak dosis $200 \mathrm{mg} / \mathrm{kg} \mathrm{BB}, 400 \mathrm{mg} / \mathrm{kg}$ BB dan 800 $\mathrm{mg} / \mathrm{kg} \mathrm{BB}$, sehingga dilanjutkan dengan uji post hoc LSD untuk melihat perbedaan yang bermakna antar kelompok perlakuan. Hasil uji post hoc $L S D$ menunjukkan bahwa kontrol positif berbeda signifikan dengan kontrol sakit tetapi tidak berbeda sigifikan dengan kelompok dosis $200 \mathrm{mgkg} \mathrm{BB}, 400 \mathrm{mg} / \mathrm{kg}$ BB dan $800 \mathrm{mg} / \mathrm{kg}$ BB. Hal ini menunjukan bahwa semua kelompok dosis $200 \mathrm{mgkg} \mathrm{BB}, 400 \mathrm{mg} / \mathrm{kg} \mathrm{BB}$ dan $800 \mathrm{mg} / \mathrm{kg}$ BB sudah mampu menurunkan kadar glukosa darah hewan uji yang sebanding dengan penurunan pada kontrol positif yang artinya ekstrak etanol daun kemangi memiliki efek yang sebanding dengan glibenklamid yang merupakan obat anti diabetes yang sering dikonsumsi oleh penderita diabetes.

Kelompok perlakuan yang diberikan ekstrak daun kemangi dengan tiga variasi dosis semuanya memiliki efek dalam menurunkan kadar glukosa darah, akan tetapi dari ke tiga dosis tersebut, dosis $800 \mathrm{mg} / \mathrm{kg}$ BB memberikan penurunan kadar glukosa darah hewan uji yang sebanding dengan kontrol positif. Berdasarkan hasil statistik maka dosis $800 \mathrm{mg} / \mathrm{kg}$ BB merupakan dosis yang efektif dalam menurunkan kadar glukosa darah hewan uji.

Senyawa yang terkandung dalam ekstrak daun kemangi yang berperan dalam menurunkan kadar glukosa darah adalah flavonoid, saponin dan tanin. Flavonoid berperan dalam menurunkan kadar glukosa darah dengan cara meningkatkan sekresi insulin di sel $\beta$ pankreas. Selain itu, flavonoid dapat mencegah kerusakan sel $\beta$ pankreas karena memiliki aktivitas sebagai antioksidan yang bekerja dengan cara menangkap atau menetralkan radikal bebas yang terkait dengan gugus $\mathrm{OH}$ sehingga dapat memperbaiki keadaan jaringan yang rusak (Andrie, 2014). Saponin dapat menurunkan kadar glukosa darah dengan cara meningkatkan sekresi insulin di sel $\beta$ pankreas, meningkatkan uptake glukosa dan menghambat penyerapan glukosa didalam usus halus (Ramadani, 2016). Tanin bekerja sebagai antihiperglikemia dengan cara meningkatkan glikogenesis. Selain itu, tanin juga berfungsi sebagai astringen yang dapat mengerutkan membran epitel usus halus sehingga menghambat penyerapan glukosa dan pada akhirnya akan menurunkan kadar glukosa darah (Andrie, 2014).

Hasil pengamatan preparat histopatologiKelompokekstrak etanol daun kemangi dosis $200 \mathrm{mg} / \mathrm{kgBB}$ terjadi perubahan menunjukkan adanya penurunan kerusakan dibandingkan dengan kontrol negatif tetapi penurunan kerusakanya kecil. Pada kelompok ekstrak etanol daun kemangi dosis 400 $\mathrm{mg} / \mathrm{kgBB}$ tampak adanya sel yang tidak normal terjadi perubahan dari batas organ pulau langerhans menjadi tidak jelas, jumlah sel mulai berkurang serta tidak terjadi nekrosis pada sel hanya terlihat degenerasi. Hal ini menunjukkan adanya penurunan tingkat kerusakan dibandingkan dengan kontrol negatif. Penurunan ini lebih baik dibandingkan dengan dosis $200 \mathrm{mg} / \mathrm{kgBB}$ karena pada dosis $400 \mathrm{mg} / \mathrm{kgBB}$ dan $800 \mathrm{mg} / \mathrm{kgBB}$ jumlah zat aktif lebih banyak dibandingkan dengan dosis 200mg/kgBB 
sehingga efek yang ditimbulkan jauh lebih baik.

\section{KESIMPULAN}

Berdasarkan hasil penelitian dan pembahasan maka dapat disimpulkan bahwa:

1. Senyawa metabolit sekunder yang terdapat pada ekstrak etanol daun keamngi yaitu flavonoid, tannin dan saponin.

2. Pemberian ekstrak etanol daun kemangi,mempunyai pengaruh terhadap penurunan kadar glukosa darah, dan perbaikan pulauLangerhans tikus putih jantan yang diinduksi streptozotocin

\section{DAFTAR PUSTAKA}

American Diabetes Association (ADA).2004. Diabetic Neuropathies.Vol 28.

Andrie, M., Wintari, T., Ayunda, R. (2014). Uji aktivitas jamu gendong kunyit asam (Curcuma domestica Val.; Tamarindus indica L.,) sebagai antidiabetes pada tikusyang diinduksi streftozotocin. Traditional Medicine Journal, 19(2), 95-102

Ayunda, Rizqi.2014” Uji aktifitas ekstrak tanaman kunyit asam (Curcuma domestica Val; Tamarindus indica L.)Universitas tanjungpura pontianak: Hal :19

Aer natalia brenda, Citraningtyas gayatri. 2013. Uji Efek Ekstrak Kulit Terung Ungu (Salanun melongena L.) Terhadap Kadar Gula Darah Tikus Putih Jantan Galur Wistar (Ranttus novergicus). Pharmacon Jurnal Ilmiah Farmasi-UNSRAT. Vol 2. No 4. Hal 2.

Dwinthasari., M.A. 2015. Uji Aktivitas Serbuk Jamur Tiram Putih (Pleurontasonstracatus (Jacq) P. Kumm) Terhadap Kadar Glukosa Darah pada Model Hewan Hiperkolestrolmia Diabetes. Gelanika. Journal of pharmacy. Vol 3(1) : 42-48.

Ezeani et al, 2016,Ocimum basilicum extract exhibits antidiabetic effects via inhibition of hepatic glucose mobilization and carbohydrate metabolizing enzymes, Journal of
Intercultural

Ethnopharmacology:Hal.25-26.

Ikhlas nur. 2013. Uji aktivitas Antioksidan Ekstrak Herba Kemangi (Ocimum americanum Lim.) Dengan Metode DPPH (2,2 Difenil-1-Pikrilhidrazil). UIN Syarif Hidayatullah. Hal 8

Laxmi nur suci, Nur kuswanti, Tjandrakirana. 2017. Pengaruh Filtrat Kulit Buah Naga Merah (Hylocereus polyrhizus) Terhadap Kadar Glukosa Darah Mencit (Mus musculus) Yang Diinduksi Glukosa. Lentera Bio. Vol 6. No 1. Hal 1.

Manasika Ariana. 2014. Uji Aktivitas Antidiabetes Ekstrak Etanol Daun Kemangi (Ocimum Basilicum L.) Pada Mencit Jantan Galur Balb-C Yang Diinduksi Aloksa. Jember. Hal 9.

PEERKENI.2015.Pengelolaan dan Pencegahan Diabetes Melitus Tipe 2 di Indonesia. Perkumpulan Endokrinologi Indonesia. Hal.1-2

Santi Damayanti.2015.Diabetes mellitus dan penatalaksanaan keperawatan Edisi 1.Penerbit Nuha medika.yogyakarta.Hal $15,6$.

Savira intan. 2012. Pengaruh Ekstrak Daun Kemangi (Ocimum santum L.) Terhadap penurunan Kadar SGPT Tikus Putih Jantan (Ranttus novergicus) Yang Diinduksi Paracetamol. Perpustakaan. uns.ac.id. Hal 3.

Sari, D.P. 2016. Efek Antidiabetes Ekstrak Daun Asam Jawa (Tamarindus indica L.) Terhadap Tikus Putih Jantan (Rattus norvegicus) yang Diinduksi Streptozotocim.hal. 7-10

Suryani, N., Tinny E.H., Aulanni'am. 2013. Pengaruh Ekstrak Metanol Biji Mahoni Terhadap Peningkatan Kadar Insulin, Penurunan Ekspresi TNF- $\alpha$ dan Perbaikan Jaringan Pankreas Tikus Diabetes. Jurnal Kedokteran Brawijaya 27 (3), 137-145.

Tandi, J. 2016. Buku ajar Obat tradisional.Edisi IV,Sekolah Tinggi Ilmu Farmasi, Palu.ISBN 978-602-74003-13.

Tandi,J. 2017. Efek ekstrak etanol daun sukun (Artocarpus altilis (Parkinson ExF.A.Zorn) terhadap penurunan kadar glukosa darah, kolestrol total dan gambaran histopatologi pankreas tikus putih jantan (Rattus norvegicus) hiperkolestrolemia diabetes. vol1. No8.p-ISSN: 23030267, e-ISSN: 24076082. 
Tandi, J. 2018. UjiEfek ekstrak etanol daun nangka (Artocarpus heterophyllus Lamk) terhadap gambaran histopatologi pankreas tikus putih jantan yang diinduksi streptozotocin Vol XV No.2 Agustus $2018 p$ ISSN: 1907-7378: eISSN: 2559-1558

Tandi,J.2017. Efek Ekstrak Etanol Daun jambu air(Syzgium aqueum(Burm.f) Alston) terhadap histopatologi pankreas tikus putih. Vol XV No.1 $p$ ISSN: 19077378: $e$ ISSN: 2559-1558.

Tandi, J. 2017. Effect of Extract of Kenikir (Cosmos caudatus Kunth.) Leaves to the Decrease in Blood Glucose, Cholestrol and Toward Histopatology Pancreas Description in Male With Rats (Rattus norvegicus) Hypercholestrolemia. Jurnal Trop Pharmacy Vol.o1 No.01.

Tandi, J. 2017. Effect of Ethanol Extract Gendola Leaf (Basella alba L.) On Decreasing Blood Glucose Condition And Histopatology Pancreas White Rats (Rattus norvegicus) Inducated Streptozotocin. Journal of Islamic Medicine Research. Vol.1 No.2.

Tandi, J. Rizky, M. Mariani, R. Alan, F. 2017. Uji Efek Ekstrak Etanol Daun Sukun (Artocapus asrtilis (Parkinson Ex FA Zorn) Terhadap Penurunan Kadar Glukosa Darah Kolestrol Total dan Gambaran Histopatologi Pankreas Tikus Putih Jantan (Rattus norvegicus) Hiperkolestrolemia-Diabetes Melitus. Jurnal Sains dan Kesehatan. Vol.1 No.8.

Tandi. J. 2018. Analisis Daun Gedi Merah (Abelmoscus manihot (L.) Medik) Sebagai Obat Diabetes Melitus. Buku Kedokteran EGC. ISBN : 978-979-044874-2.

Tandi J. 2016. Buku Ajar Farmasi Klinik I. STIFA Pelita Mas Palu Press. Hal.110. ISBN 978-602-74003-1-1.

Tandi J, Dermiati T, Cherly Dwianita. 2017. Pengaruh pemberian ekstrak etanol daunt alas (Colocasia esculenta (L.) Schoot) terhadap penurunan kadar kolestrol total darah tikus putih jantan (Rattus norvegicus) yang diinduksi pakan tinggi lemak dan streptozotocin.

Tandi, J. Ayu Wulandari, Asrifa, A. 2016. Efek Ekstrak Etanol Daun Gendola Merah (Basella alba L.) terhadap Kadar Kreatinin, Ureum dan Deksripsi Histologis Tubulus Ginjal Tikus Putih Jantan (Rattus norvegicus) Diabetes yang diinduksi streptozotocin. Galenika
Journal of Pharmacy. 3(2): 93-8744. EISSN: 2442-8744.

Tandi. J. Suryani As'ad, Rosdiana Natzir, Agussalim Bukhari. 2016. Test of Ethanol Ekstrak Red Gedi Leaves (Abelmoscus manihot (L.) Medik) in White Rat (Rattus norvegicus) Type 2 Diabetes Mellitus, International Journal of Sciences : Basic and Applied Research 30 (2016), 84-94

Tandi J, Danthy R, Purwaningsih, Kuncoro H,.2019.Effect of Ethanol Extract from Purple Eggplant Skin (Solanum melongena L) On Blood Glucose Levels and Pancreatic B Cells Regeneration on White Rats Male HypercholesterolemiaDiabetic. Research Journal of Pharmacy and Technology, Vol 12 No.6. ISSN Online : o974-360X. Hal : 2936-2942

Tandi J. Ida Yanti Palinggi Seblin Tonapa Rammang Tien Wahyu Handayani. 2019. Uji Efektivitas Antihiperglikemia Daun Kelor (Moringa Oleifera Lam.) Dan Gambaran Histopatologi Pankreas Tikus Putih Jantan (Rattus Norvegicus) Yang Diinduksi Streptozotocin, Jurnal Jamu Indonesia, Vol 4 No.2. ISSN : 2407-7663. Hal : 63-73

Wibowo adi arianto. 2012. Pengaruh Ekstrak Daun Kemangi (Ocimum santum L.) Terhadap Penurunan Kadar Kreatinin Dalam Darah Tikus Putih (Ranttus novergicus) Yang Diinduksi Paracetamol. Perpustakaan.uns. ac.id. Hal 6. 